Original Research

\title{
PENGARUH PERBEDAAN KONSENTRASI DAN UJI STABILITAS EKSTRAK ETANOL 96\% DAUN URANG ARING (Eclipta alba L. Hassk) DALAM SEDIAAN GEL TERHADAP AKTIVITAS ANTIBAKTERI Propionibacterium acnes DAN Staphylococcus epidermidis
}

\author{
THE INFLUENCE OF THE CONCENTRATION AND THE STABILITY EXTRACT \\ ETHANOL 96\% LEAVES URANG ARING (Eclipta alba L. Hassk) IN \\ PREPARATION FOR THE ANTIBACTERIAL ACTIVITY Propionibacterium \\ acnes AND Staphylococcus epidermidis
}

\author{
Hanifah Nurani ${ }^{1}$,Marta Halim ${ }^{2}$ \\ Fakultas Farmasi, Universitas 17 Agustus 1945 Jakarta, Jakarta, Indonesia, 14350 \\ *E-mail: pharmartacist@gmail.com
}

\begin{abstract}
Abstrak
Daun urang aring (Eclipta alba L. Hassk) memiliki aktivitas farmakologi diantaranya sebagai antibakteri, antivirus, antioksidan dan analgesik. Tujuan penelitian ini untuk mengetahui apakah ekstrak etanol 96\% Daun Urang Aring (Eclipta alba L. Hassk) dalam sediaan gel dapat memberikan aktivitas antibakteri terhadap bakteri Propionibacterium acnes dan Staphylococcus epidermidis. Metode uji menggunakan metode difusi cakram dengan menguji ekstrak dan memformulasikan dalam sediaan gel dengan konsentrasi 2,5\%,5\%, 10\%, 20\% dan 50\% dengan HPMC sebagai basisnya. Hasil penelitian menunjukkan bahwa ekstrak dan sediaan gel memiliki aktivitas antibakteri, pada konsentrasi 2,5\% Daun Urang Aring (Eclipta alba L. Hassk) dapat menghambat pertumbuhan bakteri Staphylococcus epidermidis dan Propionibacterium acnes pada konsentrasi 2,5\% dengan zona hambat masing-masing sebesar 6,37 $\mathrm{mm}$ dan $6,52 \mathrm{~mm}$. Stabilitas sediaan gel pada uji organoleptik tidak didapatkan adanya perubahan warna, rasa, bau dan bentuk. Sediaan gel homogen, dengan $\mathrm{pH}$, daya sebar dan viskositas sesuai selama 4 minggu pada suhu yang berbeda $\left(4^{\circ} \mathrm{C}, 25^{\circ} \mathrm{C}, 40^{\circ} \mathrm{C}\right)$.
\end{abstract}

Kata kunci: Eclipta alba L. Hassk, Antibakteri, Gel, Propionibacterium acnes, Staphylococcus epidermidis

\begin{abstract}
Leaves urang aring (Eclipta alba L. Hassk) having activity pharmacology namely antibacterial, an antiviral, antioxidants and analgesic. The purpose of this research to see if extract ethanol 96\% leaves urang aring (Eclipta alba L. Hassk) in preparation gel can provide antibacterial activity against Propionibacterium acnes and Staphylococcus epidermidis. Tested methods in a diffusion discs examination of extract and formulating in preparation gel with low 2,5\%, 5\%, 10\%, 20\% and 50\% with HPMC as its base. The result showed that extract and gel having preparations antibacterial activity, on the concentration 2,5\% leaves urang aring (Eclipta alba L. Hassk) could hinder the growth of bacteria Staphylococcus epidermidis and Propionibacterium acnes on concentration 2,5\% with zones obstruent respectively of $6,37 \mathrm{~mm}$ and $6,52 \mathrm{~mm}$. Preparations stability gel by the experiment organoleptic does not obtain of changes in color, think, smell and shape. Preparation, homogeneous gel with the ph, the spread and viscosity appropriate 4 during sunday at different temperatures $\left(4^{\circ} \mathrm{C}, 25^{\circ} \mathrm{C}, 40^{\circ} \mathrm{C}\right)$.
\end{abstract}


Keywords: Eclipta alba L. Hassk, Antibacterial, Gel, Propionibacterium acnes, Staphylococcus epidermidis

\section{PENDAHULUAN}

Jerawat merupakan suatu penyakit kulit yang disebabkan adanya peradangan yang menahun. Bakteri yang biasanya menginfeksi jerawat adalah Staphylococcus epidermidis dan Propionibacterium acnes.

Propionibacterium acnes adalah bakteri yang berperan pada pathogenesis jerawat yang dapat menyebabkan inflamasi. Propionibacterium acnes merupakan bakteri yang pertumbuhannya relative lambat, berbentuk batang tidak beraturan, dapat tumbuh diudara dan termasuk kedalam bakteri gram positif. Sedangkan Staphylococcus epidermidis umumnya dapat menimbulkan penyakit pembengkakan (abses) seperti jerawat, infeksi kulit, infeksi saluran kemih dan infeksi ginjal [1]. Staphylococcus epidermidis merupakan salah satu bakteri Gram Positif, biasanya tersusun tidak beraturan seperti anggur dan bersifat anaerob fakultatif.

Berbagai antibakteri banyak ditemukan pada bahan alam, salah satunya yaitu pada tumbuhan. Tumbuhan merupakan dasar suatu sistem dari pengobatan tradisional sejak beberapa tahun silam dan dikembangkan dengan ilmu pengetahuan sehingga menghasilkan hasil yang lebih baik dari sebelumnya [2].

Salah satu tumbuhan yang memiliki potensi untuk dikembangkan sebagai obat tradisional adalah daun urang aring (Eclipta alba L. Hassk). Daun urang aring (Eclipta alba L. Hassk) memiliki aktivitas farmakologi diantaranya sebagai antibakteri, antivirus, antioksidan, analgesic [3].

Hasil penapisan fitokimia secara kualitatif menunjukkan bahwa ekstak etanol daun urang aring mengandung golongan senyawa seperti flavonoid, kuinon, tanin (galat dan katekalat), dan streroid/triterpenoid yang telah diteliti oleh [4]. Senyawa flavonoid diduga mekanisme kerjanya mendenaturasi protein sel bakteri dan merusak membran sel tanpa dapat diperbaiki lagi [5].

Tanaman urang aring dengan senyawa flavonoid memiliki aktivitas antibakteri yang dapat dibuat sediaan yang aman, nyaman dan praktis untuk sediaan jerawat, misalnya sediaan gel. Gel merupakan sediaan semisolid dengan basis yang mudah dicuci sehingga besar harapan dapat disenangi oleh masyarakat karena penggunaannya yang lebih praktis.

Berdasarkan pemaparan diatas, penulis tertarik untuk melakukan penelitian dengan menguji aktivitas antibakteri ekstrak daun urang aring (Eclipta alba L. Hassk) dalam sediaan gel terhadap bakteri penyebab jerawat Propionibacterium acnes dan Staphylococcus epidermidis. 


\section{METODE}

\section{Alat}

Neraca analitik (Boeco Germany®), oven (Memmert®), Rotary evaporator, wadah maserasi, tabung reaksi (Pyrex $®)$, botol timbang, piknometer, kurs porselen, tanur (Nabertherm $\left.{ }^{\circledR}\right)$, desikator, penangas air (Memmert ${ }^{\circledR}$ ), cawan uap, corong gelas, spatel logam, batang pengaduk kaca, penjepit kayu, pinset, labu ukur 10 mL (Duran ${ }^{\circledR}$ ), Laminar Air Flow (Innotech®), autoklaf (Hirayama $\left.{ }^{\circledR}\right)$, incubator (Memmert $\left.{ }^{\circledR}\right)$, kompor listrik (Maspion $\left.{ }^{\circledR}\right)$, hotplate, stirrer magnetic, vortex (Genie2®), pipet mikro dan mikro tips, ball pipet (Marienfeid $\left.{ }^{\circledR}\right)$, lampu spiritus, ose, cawan

petri, jangka sorong (Wipro ${ }^{\circledR}$ ), gelas objek, staining dish, mikroskop, gelas ukur (Iwaki ${ }^{\circledR}$ ), beaker glass (Duran $\left.{ }^{\circledR}\right)$, Erlenmeyer (Duran $\left.{ }^{\circledR}\right)$, viscometer Brookfield, Moisture Analyzer.

\section{Bahan}

Simplisia daun urang aring (Eclipta alba L. Hassk), aquadest, NaCL 0,9\% steril, etanol 96\%, disk antibiotik klindamisin, blank disk, kloroform, $\mathrm{FeCl}, \mathrm{HCl}$, Logam $\mathrm{MgO}$, amil alkohol, pereaksi Mayer, pereaksi Dragendorf, pereaksi Bouchardad, $\mathrm{NH}_{4} \mathrm{OH}, \mathrm{CHCl}_{3}$, asam asetat anhidrat, $\mathrm{H}_{2} \mathrm{SO}_{4}$, metil paraben, propilen glikol, propil paraben, HPMC (Hidroksi Propil Metil Selulosa), alkohol $70 \%$.

\section{Prosedur kerja}

\section{Preparasi dan Ekstraksi}

Sampel daun urang aring (Eclipta alba L. Hassk) diperoleh dari Balitro, Bogor. Sampel terlebih dahulu dilakukan sortasi basah, kemudian dicuci dengan air mengalir, ditiriskan dengan cara diangin-anginkan, lalu dilakukan sortasi kering, kemudian diserbukkan. Simplisia yang sudah kering diekstraksi menggunakan etanol 96\% dan diaduk sesekali selama 24jam. Proses ekstraksi diulang sebanyak $3 \mathrm{kali}$ dengan cara yang sama. Maserat yang diperoleh dipekatkan dengan rotary evaporator. 


\section{Rancangan Formula}

Tabel 1. Formula Gel Ekstrak Daun Urang Aring

\begin{tabular}{|c|c|c|c|c|c|c|}
\hline \multirow{2}{*}{ Nama Bahan } & \multicolumn{5}{|c|}{ Formula (b/v) } & \multirow{2}{*}{ Fungsi } \\
\cline { 2 - 7 } & F I & F II & F III & F IV \\
$\mathbf{2 , 5 \%}$ & $\mathbf{5 \%}$ & $\mathbf{1 0 \%}$ & $\mathbf{2 0 \%}$ & $\mathbf{5 0 \%}$ & \\
\hline Ekstrak daun uranng aring & 1,25 & 2,5 & 5 & 10 & 25 & Zat aktif \\
\hline HPMC & 1,5 & 1,5 & 1,5 & 1,5 & 1,5 & Gelling Agent \\
\hline (Hidroksi Propil Metil Selulosa) & 7,5 & 7,5 & 7,5 & 7,5 & 7,5 & Humektan \\
\hline Propilen glikol & 0,09 & 0,09 & 0,09 & 0,09 & 0,09 & Pengawet \\
\hline Metil paraben & 0,01 & 0,01 & 0,01 & 0,01 & 0,01 & Pengawet \\
\hline Propil paraben & ad & ad & ad & ad & ad & Pelarut \\
\hline Aquadest & $50 \mathrm{ml}$ & $50 \mathrm{ml}$ & $50 \mathrm{ml}$ & $50 \mathrm{ml}$ & $50 \mathrm{ml}$ & \\
\hline
\end{tabular}

\section{Pembuatan Gel Ekstrak Etanol 96\% Daun Urang Aring}

Aquadest sebanyak 50mL dipanaskan hingga mendidih, kemudian diangkat dan HPMC dikembangkan di dalamnya selama lebih kurang 15 menit, setelah mengembang kemudian ditambahkan metil paraben dan propil paraben yang sebelumnya dilarutkan dengan air panas, propilen glikol digerus bersama ekstrak dauun urang aring dicampurkan sampai homogen, lalu dicukupkan dengan aquadest sampai 50mL [6].

\section{Evaluasi Sediaan Fisik Gel}

Evaluasi yang dilakukan meliputi uji organoleptik, pengjian homogenitas, pengujian $\mathrm{pH}$, pengujian daya sebar dan pengujian viskositas.

\section{Uji Aktivitas Antibakteri Formulasi Gel Ekstrak Daun Urang Aring Terhadap Propionibacterium acnes dan Staphylococcus epidermidis}

Semua peralatan dan bahan yang akan digunakan disterilkan terlebih dahulu. Kemudian buat suspensi bakteri Staphylococcus epidermidis dan Propionibacterium acnes dari biakan bakteri dengan menggunakan $\mathrm{NaCl}$ 0,9\% sesuaikan dengan standar Mc. Farland 0,5. Siapkan media Mueller Hinton Agar untuk bakteri Staphylococcus epidermidis dan Mueller Hinton Agar ditambahkan darah domba 5\% untuk bakteri Propionibacterium acnes yang sudah disterilkan, setelah itu taruh cawan petri sekitar 15 - $20 \mathrm{~mL}$. Selanjutnya, suspensi bakteri dalam $\mathrm{NaCl} \mathrm{0,9 \%}$ 
diambil dengan kapas steril selanjutnya diusapkan pada media Mueller Hinton Agar yang ditambahkan darah domba 5\%. Kemudian siapkan larutan yang akan diuji dan di teteskan dengan menggunakan mikropipet pada disk steril. Kemudian setelah itu di inkubasi pada suhu $37^{\circ} \mathrm{C}$ sebanyak 24 - 48 jam, semua tahap perlakuan dilakukan di Laminar Air Flow (LAF). Dan dilihat dari zona bening disekitar disk, di ukur menggunakan jangka sorong. Uji dilakukan dengan 3 kali pengulangan.

\section{HASIL DAN PEMBAHASAN}
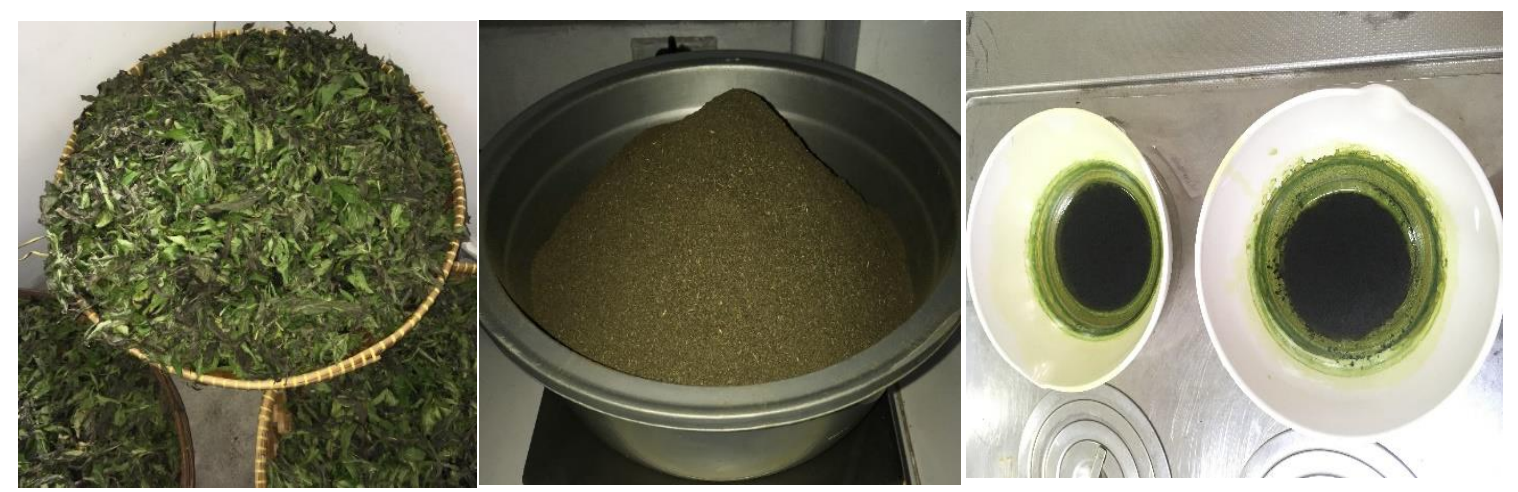

Gambar 1. Daun Kering, Serbuk, Ekstrak Kental Daun Urang Aring

Setelah didapatkan ekstrak etanol $96 \%$ daun urang aring, perlu dilakukan pemeriksaan karakteristik ekstrak meliputi uji organoleptis, perhitungan nilai rendemen, pengukuran susut pengeringan, kadar air, kadar abu, kadar sisa pelarut serta skrining fitokimia. Hasil uji karakteristik ekstrak terlihat pada Tabel 2.

Tabel 2. Uji Karakteristik Ekstrak Etanol $96 \%$ daun urang aring (Eclipta alba L. Hassk)

\begin{tabular}{|c|c|}
\hline Uji Karakteristik & $\begin{array}{c}\text { Ekstrak Etanol 96\% Daun } \\
\text { Urang Aring }\end{array}$ \\
\hline Organoleptis : & Kental \\
a. Bentuk & Hijau Tua \\
b. Warna & Khas \\
\hline c. Bau & $8,18 \%$ \\
\hline Rendemen & $9,5 \%$ \\
\hline Susut Pengeringan & $4,33 \%$ \\
\hline Kadar Air & $1,0 \%$ \\
\hline Kadar Abu & $0,5 \%$ \\
\hline Kadar Sisa Pelarut Etanol $70 \%$ & \\
\hline
\end{tabular}


Tabel 3. Hasil Uji Aktivitas Antibakteri Ekstrak Daun Urang Aring Terhadap Staphylococcus epidermidis

\begin{tabular}{|c|c|c|c|c|c|c|c|r|}
\hline Bakteri & Pengulangan & \multicolumn{7}{|c|}{ Konsentrasi } \\
\hline \multirow{3}{*}{$\begin{array}{c}\text { S. } \\
\text { epidermidis }\end{array}$} & & $50 \%$ & $20 \%$ & $10 \%$ & $5 \%$ & $2,5 \%$ & $\mathrm{KKP}$ & $\mathrm{KKN}$ \\
\cline { 2 - 9 } & 2 & 11,66 & 10,86 & 9,35 & 8,55 & 7,67 & 13,86 & 6,35 \\
\cline { 2 - 9 } & 2 & 11,62 & 10,80 & 9,39 & 8,59 & 7,62 & 13,90 & 6,39 \\
\hline \multicolumn{2}{|c|}{ Rata-rata } & 11,69 & 10,85 & 9,33 & 8,53 & 7,66 & 13,84 & 6,37 \\
\cline { 2 - 9 } & 3 & 11,65 & 10,83 & 9,35 & 8,55 & 7,65 & 13,86 & 6,37 \\
\hline
\end{tabular}

Tabel 4. Hasil Uji Aktivitas Antibakteri Ekstrak Daun Urang Aring Terhadap Propionibacterium acnes

\begin{tabular}{|l|c|c|c|c|c|c|c|c|}
\hline Bakteri & Pengulangan & \multicolumn{7}{|c|}{ Konsentrasi } \\
\hline \multirow{4}{*}{ P.acnes } & & $50 \%$ & $20 \%$ & $10 \%$ & $5 \%$ & $2,5 \%$ & KKP & KKN \\
\cline { 2 - 9 } & 1 & 12,95 & 11,78 & 9,91 & 9,14 & 7,26 & 13,44 & 6,56 \\
\cline { 2 - 9 } & 2 & 12,99 & 11,76 & 9,94 & 9,19 & 7,23 & 13,49 & 6,59 \\
\cline { 2 - 9 } & 3 & 12,92 & 11,83 & 9,89 & 9,12 & 7,27 & 13,46 & 6,54 \\
\hline \multicolumn{2}{|c|}{ Rata-rata } & 12,95 & 11,79 & 9,91 & 9,15 & 7,25 & 13,56 & 6,50 \\
\hline
\end{tabular}

Berdasarkan dari data hasil pengujian aktivitas antibakteri ekstrak etanol daun urang aring terhadap bakteri Staphylococcus epidermidis dan Propionibacterium acnes menunjukkan bahwa disk yang diolesi dengan basis gel atau sediaan gel tetapi tanpa adanya penambahan ekstrak digunakan sebagai kontrol negatif dan memberikan adanya zona hambat yakni sebesar $6,37 \mathrm{~mm}$ pada bakteri Staphylococcus epidermidis, sedangkan pada bakteri Propionibacterium acnes memberikan zona hambat sebesar $6,50 \mathrm{~mm}$. Hal ini dapat terjadi karena didalam formulasi sediaan gel ditambahkan metil paraben dan propil paraben yang ditambahkan secara bersamaan yang mamiliki sifat antibakteri yang biasa digunakan sebagai pengawet. Sedangkan pada klindamisin $2 \mu \mathrm{g}$ yang digunakan sebagai kontrol positif dapat menghambat pertumbuhan bakteri dengan diameter zona hambat sebesar 13,86mm pada bakteri Staphylococcus epidermidis dan pada zona hambat sebesar 13,56mm pada bakteri Propionibacterium acnes.

Hasil zona hambat bakteri dari kelima konsentrasi sediaan gel ekstrak etanol 96\% daun urang aring (Eclipta alba L. Hassk) menunjukkan adanya peningkatan zona hambat dari masingmasing konsentrasi. Jadi semakin tinggi konsentrasi sediaan gel ekstrak etanol 96\% maka semakin banyak pula kandungan senyawa metabolit sekunder yang dapat memberikan aktivitas antibakteri semakin besar.

Pada konsentrasi 2,5\% sediaan gel ekstrak etanol 96\% daun urang aring sudah dapat menghambat bakteri Staphylococcus epidermidis sebesar $7,65 \mathrm{~mm}$ dan pada bakteri Propionibacterium acnes sebesar 7,25mm. Sedangkan pada konsentrasi $50 \%$ sediaan gel ekstrak etanol $96 \%$ daun urang aring dapat menghambat bakteri Staphylococcus epidermidis sebesar $11,65 \mathrm{~mm}$ dan pada bakteri Propionibacterium acnes dapat menghambat sebesar 12,95mm. 
Tabel 5. Hasil Uji Organoleptik

\begin{tabular}{|c|c|c|c|c|c|c|c|c|}
\hline \multirow{2}{*}{ Formula } & \multicolumn{4}{|c|}{ Sebelum Penyimpanan } & \multicolumn{4}{c|}{ Sesudah Penyimpanan Selama 4 } \\
\cline { 2 - 9 } & Warna & Bau & Rasa & Bentuk & Warna & Bau & Rasa & Bentuk \\
\hline $\begin{array}{c}\text { Kontrol } \\
\text { Negatif }\end{array}$ & Bening & $\begin{array}{c}\text { Tidak } \\
\text { Berbau }\end{array}$ & $\begin{array}{c}\text { Tidak } \\
\text { Berasa }\end{array}$ & Kental & Bening & $\begin{array}{c}\text { Tidak } \\
\text { Berbau }\end{array}$ & $\begin{array}{c}\text { Tidak } \\
\text { Berasa }\end{array}$ & Kental \\
\hline FI 2,5\% & Hijau Tua & $\begin{array}{c}\text { Bau } \\
\text { Khas }\end{array}$ & $\begin{array}{c}\text { Tidak } \\
\text { Berasa }\end{array}$ & Kental & Hijau Tua & $\begin{array}{c}\text { Bau } \\
\text { Khas }\end{array}$ & $\begin{array}{c}\text { Tidak } \\
\text { Berasa }\end{array}$ & Kental \\
\hline FII 5\% & Hijau Tua & $\begin{array}{c}\text { Bau } \\
\text { Khas }\end{array}$ & $\begin{array}{c}\text { Tidak } \\
\text { Berasa }\end{array}$ & Kental & Hijau Tua & $\begin{array}{c}\text { Bau } \\
\text { Khas }\end{array}$ & $\begin{array}{c}\text { Tidak } \\
\text { Berasa }\end{array}$ & Kental \\
\hline FIII 10\% & Hijau Tua & $\begin{array}{c}\text { Bau } \\
\text { Khas }\end{array}$ & $\begin{array}{c}\text { Tidak } \\
\text { Berasa }\end{array}$ & Kental & Hijau Tua & $\begin{array}{c}\text { Bau } \\
\text { Khas }\end{array}$ & $\begin{array}{c}\text { Tidak } \\
\text { Berasa }\end{array}$ & Kental \\
\hline FIV 20\% & Hijau Tua & $\begin{array}{c}\text { Bau } \\
\text { Khas }\end{array}$ & $\begin{array}{c}\text { Tidak } \\
\text { Berasa }\end{array}$ & Kental & Hijau Tua & $\begin{array}{c}\text { Bau } \\
\text { Khas }\end{array}$ & $\begin{array}{c}\text { Tidak } \\
\text { Berasa }\end{array}$ & Kental \\
\hline FV 50\% & $\begin{array}{c}\text { Hijau } \\
\text { Kehitaman }\end{array}$ & $\begin{array}{c}\text { Bau } \\
\text { Khas }\end{array}$ & $\begin{array}{c}\text { Tidak } \\
\text { Berasa }\end{array}$ & Kental & $\begin{array}{c}\text { Hijau } \\
\text { Kehitaman }\end{array}$ & $\begin{array}{c}\text { Bau } \\
\text { Khas }\end{array}$ & $\begin{array}{c}\text { Tidak } \\
\text { Berasa }\end{array}$ & Kental \\
\hline
\end{tabular}

Pada tabel 5 hasil uji organoleptik sediaan gel ekstrak etanol 96\% daun urang aring (Eclipta alba L. Hassk) dari kelima formulasi tidak mengalami perbedaan bentuk, bau, warna dan rasa pada semua formulasi dipenyimpanan 3 suhu yaitu pada suhu $4^{\circ} \mathrm{C}, 25^{\circ} \mathrm{C}$ dan $40^{\circ} \mathrm{C}$, hal ini membuktikan bahwa sediaan gel ekstrak etanol 96\% daun urang aring (Eclipta alba L. Hassk) tetap stabil pada proses penyimpanan.

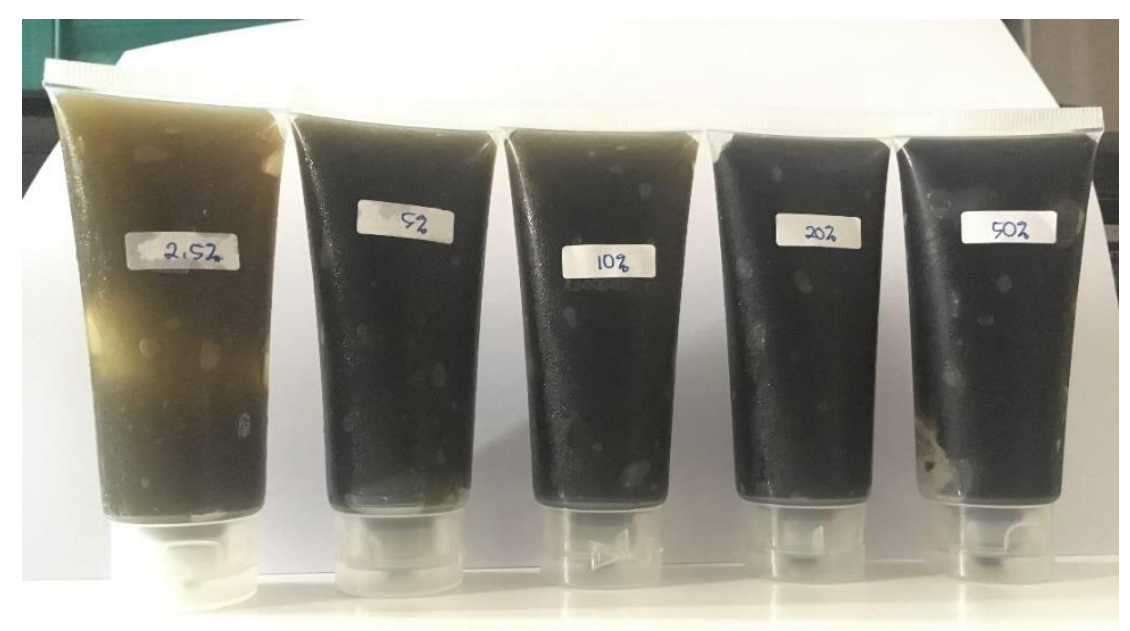

Gambar 2. Sediaan Gel Ekstrak Etanol Daun Urang Aring 
Tabel 6. Hasil Uji Homogenitas

\begin{tabular}{|c|c|c|}
\hline Formula & $\begin{array}{c}\text { Sebelum } \\
\text { Penyimpanan }\end{array}$ & $\begin{array}{c}\text { Sesudah } \\
\text { Penyimpanan } \\
\text { Selama 4minggu }\end{array}$ \\
\hline $\begin{array}{c}\text { Kontrol } \\
\text { Negatif }\end{array}$ & Homogen & Homogen \\
\hline FI 2,5\% & Homogen & Homogen \\
\hline FII 5\% & Homogen & Homogen \\
\hline FIII 10\% & Homogen & Homogen \\
\hline FIV 20\% & Homogen & Homogen \\
\hline FV 50\% & Tidak Homogen & Tidak Homogen \\
\hline
\end{tabular}

Pada tabel 6 hasil dari uji homogenitas sediaan gel ekstrak etanol 96\% daun urang aring (Eclipta alba L. Hassk) menunjukkan bahwa sediaan gel pada formulasi ke I-IV yang disimpan pada suhu $4^{\circ} \mathrm{C}, 25^{\circ} \mathrm{C}$ dan $40^{\circ} \mathrm{C}$ selama 4 minggu menunjukkan bahwa sediaan gel tetap homogen pada masing-masing suhu, karena tidak ditemukan adanya butiran-butiran halus pada saat sediaan dioleskan pada kaca objek. Sedangkan pada formulasi ke V tidak homogen pada masing-masing suhu, karena ditemukan adanya butiran-butiran halus pada saat sediaan dioleskan pada kaca objek. Hal ini terjadi karena pada saat pembuatan sediaan gel, ekstrak yang akan dicampurkan pada basis gel tidak tercampur dengan baik.

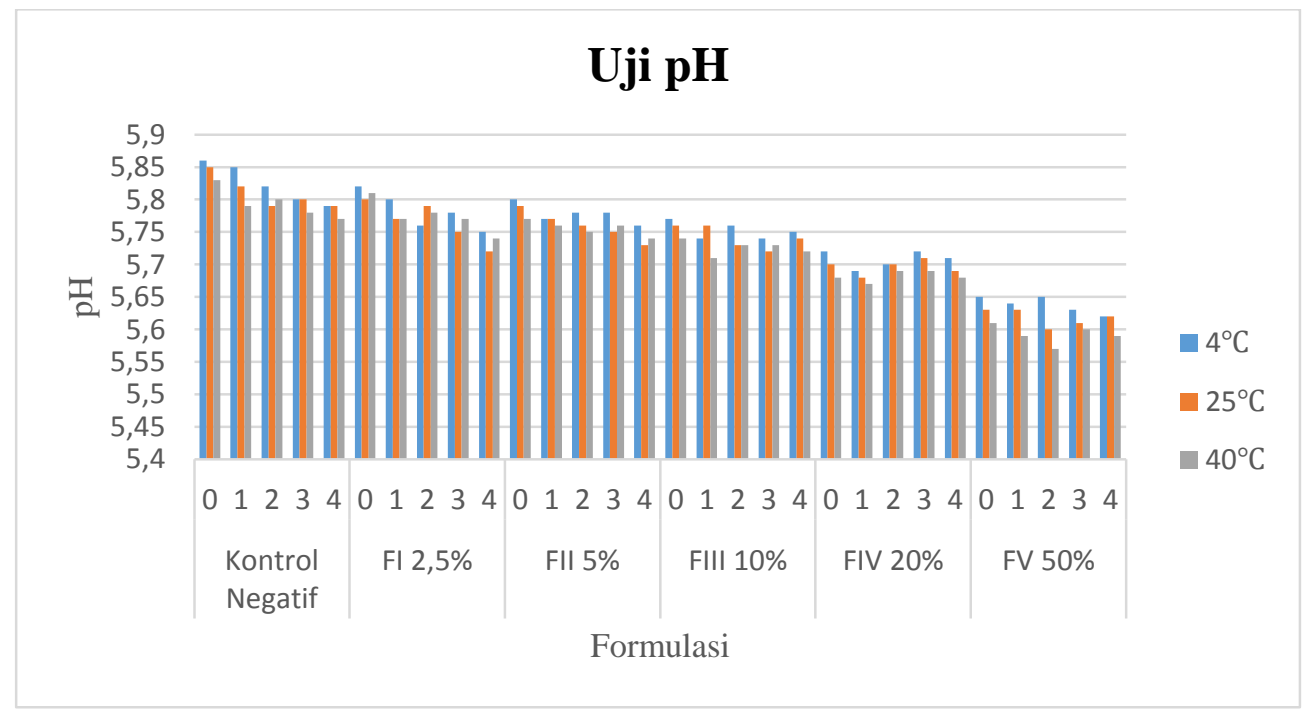

Gambar 3. Grafik Hasil Pengujian pH 
Uji $\mathrm{pH}$ dilakukan untuk mengetahui keamanan sediaan saat digunakan agar tidak terjadi iritasi pada kulit. Nilai pH untuk sediaan topikal sebaiknya berkisar pada pH kulit yaitu 4,5-6,5 [7]. Hasil stabilitas pada nilai $\mathrm{pH}$ sediaan gel ekstrak etanol $96 \%$ daun urang aring (Eclipta alba L. Hassk) pada penyimpanan 4 minggu dan dalam 3 suhu yang berbeda yakni pada suhu $4{ }^{\circ} \mathrm{C}, 25^{\circ} \mathrm{C}$ dan $40^{\circ} \mathrm{C}$ didapatkan $\mathrm{pH}$ berkisar 5,59-5,86 yang menunjukan bahwa sediaan gel masih bersifat aman karena masih berada dibawah $\mathrm{pH}$ netral sehingga tidak terlalu bersifat basa dan tidak menyebabkan iritasi pada kulit. Jika nilai $\mathrm{pH}$ terlalu asam maka akan menyebabkan kulit bersisik dan gatal-gatal, sedangkan jika nilai $\mathrm{pH}$ terlalu basa atau melampaui 7 bisa menyebabkan kulit menjadi iritasi [8].

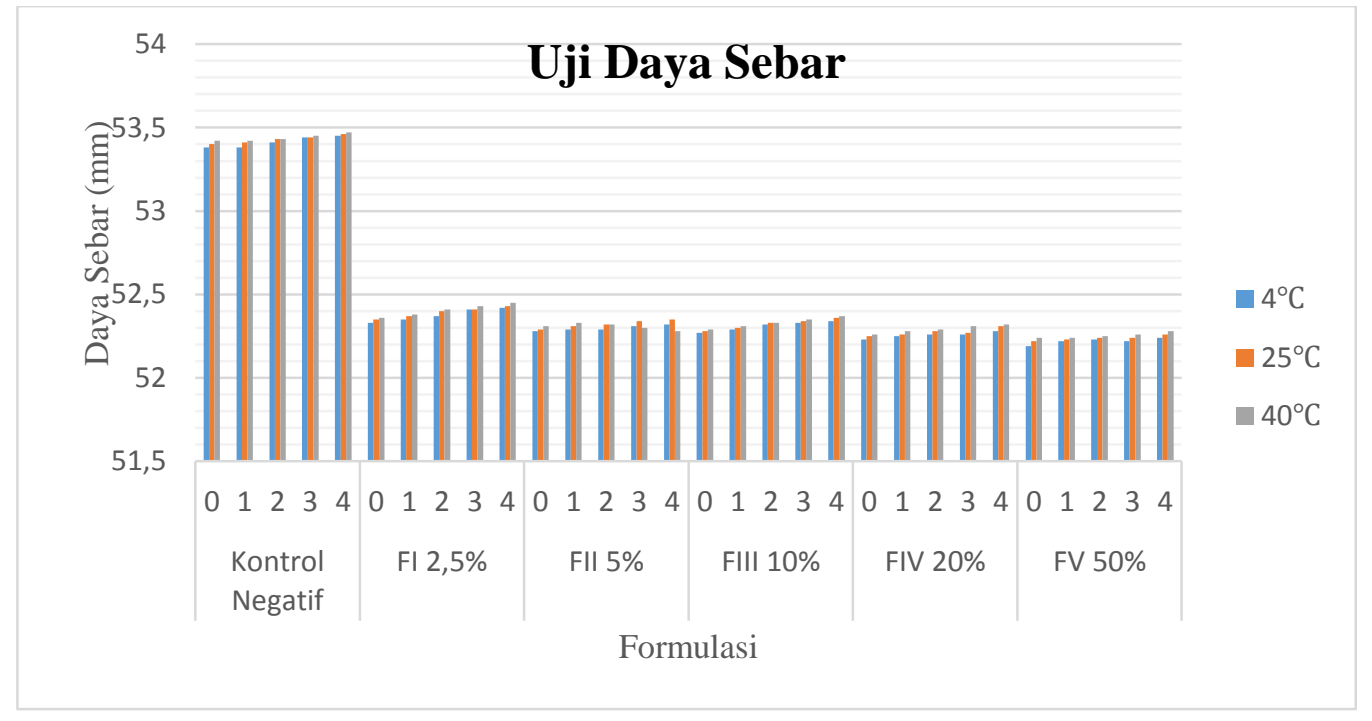

\section{Gambar 4. Grafik Uji Daya Sebar}

Uji daya sebar dilakukan bertujuan untuk melihat kemampuan sediaan menyebar pada kulit untuk menjamin pemberian obat yang memuaskan. Daya sebar yang nyaman dalam penggunaan untuk sediaan semisolid yaitu 5-7 cm [9]. Hasil dari daya sebar gel ekstrak etanol 96\% daun urang aring (Eclipta alba L. Hassk) masih dalam rentang syarat daya sebar untuk sediaan semipadat yang baik untuk penggunaan topical yakni berkisar antara 53,28mm sampai 53,38mm. 


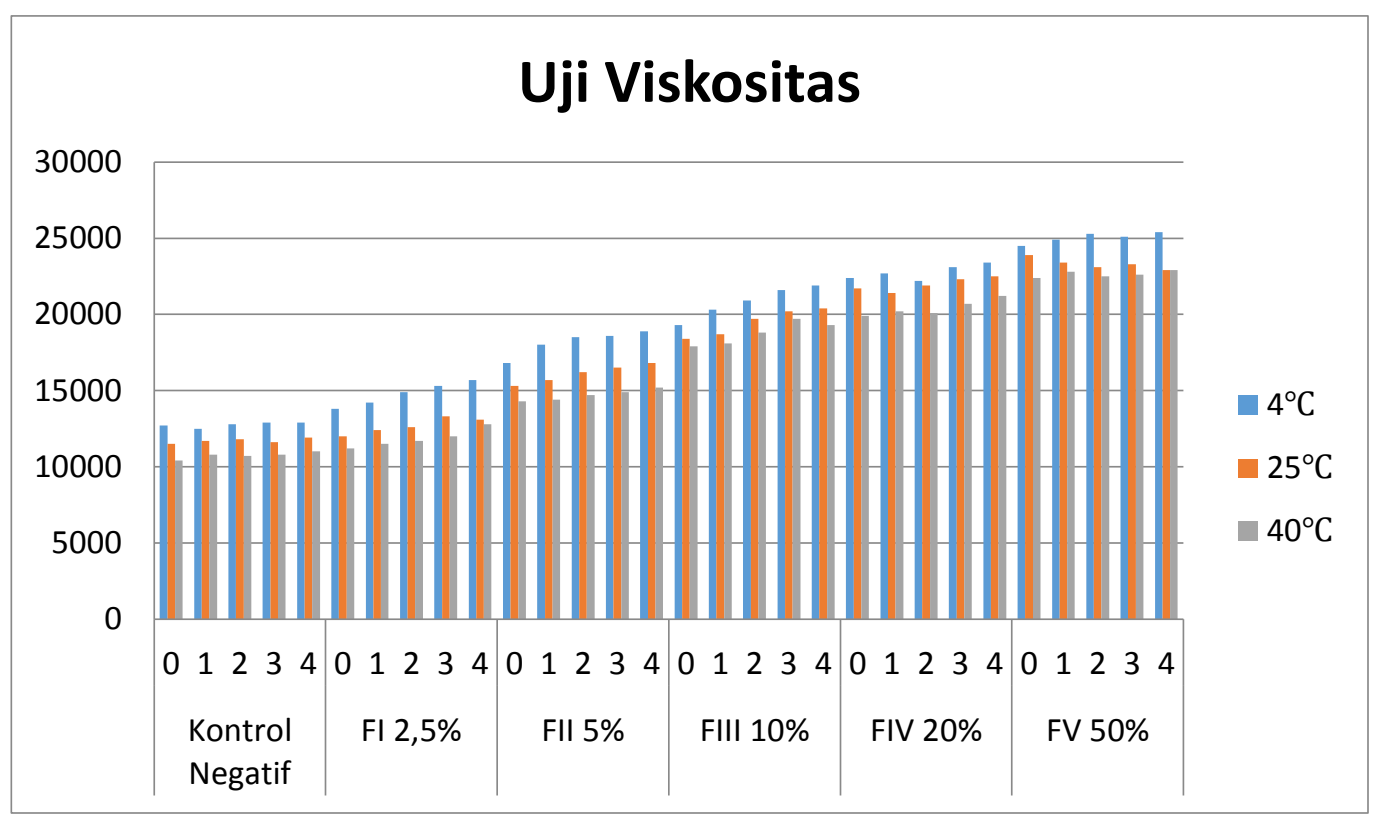

Gambar 5. Grafik Uji Viskositas

Hasil penentuan viskositas sediaan gel pada formulasi $\mathrm{I}-\mathrm{V}$ pada penyimpanan 3 suhu yang berbeda yakni pada suhu $4^{\circ} \mathrm{C}, 25^{\circ} \mathrm{C}$ dan $40^{\circ} \mathrm{C}$ selama 4 minggu menunjukkan bahwa semakin besar jumlah penambahan ekstrak etanol 96\% daun urang aring (Eclipta alba L. Hassk) semakin besar pula nilai viskositasnya. Dan semakin lama waktu penyimpanan sediaan gel maka nilai viskositasnya akan semakin besar, semakin tinggi suhu penyimpanan sediaan gel maka nilai viskositasnya akan semakin kecil.

\section{KESIMPULAN}

Semakin tinggi konsentrasi ekstrak daun urang aring sebagai bahan aktif maka semakin besar pula zona hambat yang dihasilkan. Hal ini terjadi karena dari hasil skrining fitokimia menunjukkan bahwa adanya golongan senyawa yang terkandung dalam ekstrak etanol daun urang aring meliputi flavonoid, saponin, tannin, fenol, dan alkaloid merupakan senyawa-senyawa yang diduga memiliki daya aktivitas antibakteri. Senyawa flavonoid diduga mekanisme kerjanya mendenaturasi protein sel bakteri dan merusak membran sel tanpa diperbaiki lagi. Hasil zona hambat pada bakteri Propionibacterium acnes lebih tinggi dibandingkan pada bakteri Staphylococcus epidermidis. Sediaan gel ekstrak etanol $96 \%$ daun urang aring mulai dapat menghambat pertumbuhan bakteri Staphylococcus epidermidis dan Propionibacterium acnes pada konsentrasi 2,5\% sudah dapat menghambat bakteri Staphylococcus epidermidis sebesar 7,65mm dan pada bakteri Propionibacterium acnes sebesar 7,25mm. Sedangkan pada konsentrasi 50\% sediaan gel ekstrak etanol $96 \%$ daun urang aring dapat menghambat bakteri Staphylococcus epidermidis sebesar $11,65 \mathrm{~mm}$ dan pada bakteri Propionibacterium acnes dapat menghambat sebesar $12,95 \mathrm{~mm}$. 


\section{DAFTAR RUJUKAN}

1. Radji M. Buku Ajar Mikrobiologi Panduan Mahasiswa Farmasi dan Kedokteran. Jakarta: Buku Kedokteran EGC. 2011. 107, 118, 201-207, 295.

2. Heinrich M, J. Barnes and S. Gibbons. Fundamentals of Pharmacognosy and Phytotherapy. Elsevier Science Ltd, 2009. 32-35.

3. The Wealth of India. A Dictionary of Indian Raw Material and Industrial Products. Volume 1. NISCAIR. New Delhi : CSIR, 2003. 47.

4. Sukandar EY. Tren dan Paradigma Dunia Farmasi, Industri - Klinik Teknologi Kesehatan, Orasi Ilmiah Dies Natalis ITB, Januari 2006.

5. Pelczar, M. J.; Chan E. C. S. Dasar-Dasar Mikrobiologi. Jakarta: Universitas Indonesia Press, 1988.

6. Suardi. M.; Armenia; Murhayati A. Formulasi dan Uji Klinik Gel Anti Jerawat Benzoil PeroksidaHPMC. Jurnal. Padang: Fakultas Farmasi FMIPA UNAND. 2008.

7. Tranggono, Retno I, Latifah, Fatimah. Buku Pegangan Ilmu Pengetahuan Kosmetik. Jakarta: Gramedia Pustaka Utama. 103-117.

8. Gozali, D.; Abdassah, M.; Subghan, A.; Al-Lathiefah, S. Formulasi Krim Pelembab Wajah Yang Mengandung Tabir surya Nanopartikel Zink Oksida Saut Silikon. Bandung: Farmaka, 2009.

9. Garg A, Aggarwal D, Garg dan Siglal AK. Spreading of Semisolid Formulation: An Update. Pharmaceutical Technology. 2002. 